\title{
Autism and ABA: The Gulf Between North America and Europe
}

\author{
Mickey Keenan • Karola Dillenburger • Hanns Rüdiger Röttgers • \\ Katerina Dounavi • Sigrí́xur Lóa Jónsdóttir • Paolo Moderato • \\ Jacqueline J. A. M. Schenk • Javier Virués-Ortega • Lise Roll-Pettersson • \\ Neil Martin
}

Received: 10 December 2014 / Accepted: 16 December 2014/Published online: 30 December 2014

(C) Springer Science+Business Media New York 2014

\begin{abstract}
Prevalence estimations for Autism Spectrum Disorder have been increasing over the past few years with rates now reported to be at 1:68. Interventions that are based on Applied Behaviour Analysis are significantly related to best outcomes and are widely considered 'treatment as usual' in North America. In Europe, this is not the case, instead a rather ill-defined 'eclectic' approach is widely promoted and in this paper we discuss some of the roots of this gulf between
\end{abstract}

M. Keenan $(\bowtie)$

School of Psychology, University of Ulster, Coleraine, N.

Ireland BT52 1SA, UK

e-mail: mickeykeenan@me.com

K. Dillenburger $\cdot$ K. Dounavi

Centre for Behaviour Analysis, School of Education, Queen's

University, Belfast, N. Ireland, UK

H. R. Röttgers

University of Applied Sciences, Münster, Germany

S. L. Jónsdóttir

State Diagnostic and Counselling Centre, Kópavogur, Iceland

P. Moderato

Institute of Behaviour, Consumers, Communication, IULM

University, Milan, Italy

J. J. A. M. Schenk

Department of Pedagogical \& Educational Sciences, Erasmus

University Rotterdam, Rotterdam, Netherlands

J. Virués-Ortega

School of Psychology, The University of Auckland, Auckland, New

Zealand

L. Roll-Pettersson

Specialpedagogiska institutionen, Stockholm University, Stockholm, Sweden

N. Martin

Independent Consultant, London, England, UK
Europe and North America and correct some of the misconceptions that prevail about Applied Behaviour Analysis in Europe.

Keywords Intervention $\cdot$ Scientific method $\cdot$ Parent training · Evidence-based practice $\cdot$ Applied Behaviour Analysis · ABA

The American Autism and Developmental Disabilities Monitoring Network reported estimated prevalence rates for $\mathrm{Au}-$ tism Spectrum Disorder (ASD) to be 1 in 68 (Centers for Disease Control 2013). Similar figures are recorded in the UK and across Europe (Hughes 2011). These prevalence rates place huge demands on health care systems. Economic costs associated with autism make it the most costly medical condition with an annual total cost of $\$ 61$ billion in the USA and at least $£ 3.1$ billion per year in the UK, more than heart disease, stroke and cancer combined (Buescher et al. 2014).

The common goal of autism interventions is to address quality of life issues by improving skills that can remove barriers to learning and facilitate independence and best practice utilises methods based in Applied Behaviour Analysis (ABA) (Anagnostou et al. 2014; Maurice et al. 2001). In fact, there is a highly statistically significant relationship between ABA-based interventions and optimal outcomes (Fein et al. 2013; Orinstein et al. 2014). ABA-based interventions use a data-based decision making model of programme delivery to ensure that interventions are holistic and person-centred in the sense that appropriate principles of behaviour are harnessed to meet the needs of the programme for facilitating meaningful changes in the behaviour of the individual; this means that the choice of intervention depends on the specific outcomes to be achieved and on the progress attained at any point in time (Maurice et al. 1996). Children who are in an intensive early 
ABA-based programme typically receive at least $25 \mathrm{~h}$ per week (Myers and Johnson 2007; National Research Council 2001; New York State Department of Health 1999).

The focus of this paper is to draw attention to the kinds of issues that have influenced Governmental policy support for ABA-based interventions in the USA and Canada and to examine the obstacles for both the recommendation and uptake of ABA across Europe.

\section{Gulf Between Europe and North America}

In the USA, and based on 30 years of research at the time, the Surgeon General (1999) recommended ABA as the basis of intervention for children with ASD. Since then, ABA-based interventions have been considered as medically and educationally necessary and are considered 'treatment as usual', funded through government or health care systems in the vast majority of states (38 States currently-November, 2014), federal bodies, such as the Office for Personnel Management and Medicare, and many multinational companies, such as JPMorgan Chase \& Co., Microsoft, Apple, Goldman Sachs, Intel, etc. (Autism Speaks 2014). Board Certified Behaviour Analysts (BCBA; www.bacb.com) are the professionals who supervise these programmes (frequently within licensure laws).

... ABA is not a stagnant, single continuum of prescribed methods but rather emphasizes the use of methods that change behaviour in systematic and measurable ways with an emphasis on analysis, replication, social importance, and accountability. ABA includes a large number of conceptually consistent techniques that can be used in various combinations across many different contexts whilst remaining abreast of developments in biology, medicine, and neuroscience (e.g. dietary requirements). (Anderson and Romanczyck 1999, p.167)

Agreements to introduce laws that mandate the health care system to cover autism interventions based on ABA in each of the 38 States in the USA have arisen from intense deliberations about the quality of the research evidence (Unumb 2013; Hagopian and Hardesty 2014). This evidence is substantial and includes results from

- Over 2000 replicated single system design studies

- Randomised controlled trials (RCT)

- Meta analyses

- Sequential meta analyses

- Systematic reviews

- Neuroscience (plasticity of brain)

- Social validity measures
- Cost-benefit analyses (see Larsson 2013 for an extensive list of references)

Similarly in Canada, ABA is viewed as providing the foundation for effective treatment and ABA-based services are also widely available, although the extent of coverage varies across Provinces (Autism Society Canada 2010; Autism Now 2014).

In contrast to North America, ABA-based interventions are not endorsed by governments across Europe. This is not to say that progress in the USA has been straightforward (Unumb 2013). However, there have been more professionals trained in ABA in the USA who could correct the misinformation about ABA that impeded its uptake. A paper in the Autism Europe newsletter serves as a good example of how the evidence for ABA-based interventions is ignored in Europe (Howlin 2013). While Howlin (2013) refers briefly to Lovaas (1987), who is credited with the first large-scale study on using ABA-based interventions for autism, her discussion is devoid of any reference to the extensive body of evidence supportive of the application of ABA.

This omission is all the more remarkable when you consider that Howlin's own research (Howlin et al. 2009) showed that on average children who received ABA-based interventions did much better than those who received eclectic 'treatment as usual'. While Howlin et al. noted that there were considerable benefits at the group level, they focused much more intensely on the fact that, on an individual level, not all children benefited as much. In other words, these researchers focused on the relatively short 'low impact tail' of the distribution curve rather than on the large average or the significant 'high impact tail' (cf. Dillenburger 2014). What is all the more disturbing is that these conclusions are quoted frequently in Europe in support of an argument to withhold support for ABA-based interventions (Dillenburger et al. 2010).

In a European context where training in behaviour analysis to international standards is not commonly available, it is not surprising to find that ideological assumptions can interfere with an objective appraisal of empirical data (Fazzio 2014; Keenan et al. 2010; see also video testimonials by professionals from Iceland, Italy, Sweden and the Netherlands at STAMPPP 2014). In a recent 40-year follow-up study of children diagnosed with autism in the 1970s (Howlin et al. 2014), Howlin's views about ABA appear again to be in sharp contrast to her own findings that showed extremely poor longterm outcomes of eclectic school intervention, i.e. $75 \%$ of the adults (average age 44 years) had plateaued at their 3-year-old levels whilst $25 \%$ of these adults could not even be assessed due to lack of communication skills and challenging behaviours. Howlin et al. (2014) concluded that, "[a]lthough many attended [eclectic] specialist autism schools as children... none had access to the intensive, early behavioural programs, that are available today and which are claimed, by 
some, to have a significant impact on IQ and long-term outcome" (p. 56).

This indirect endorsement of ABA by Howlin et al. is misleading because in fact, only one third (32.3\%) of young children with ASD (aged $<6$ years) in Europe are reported to receive behavioural intervention of any type, with estimates ranging from $8.6 \%$ in the Czech Republic to $80.6 \%$ in Romania (Salomone et al. 2014). Salomone et al. found that the average number of hours per week was 8.69 (range 0.64 23.00; SD 9.80). However, given that these data are based on an online survey that was completed by-and-large by welleducated parents (a common proxy for Social Economic Status; SES), it is likely the behavioural interventions are much scarcer for most children with autism in Europe, especially those living in deprived areas. When effective behavioural interventions are not supported by established academics, and consequently not implemented in local health and education systems, the real figures show considerable inequalities related to parental education and social economic status.

\section{Cultural Issues}

Apart from academic confusion (Baird 2014) and ideologically motivated omissions (Howlin 2013) or distortions (Howlin et al. 2009; 2014), there are other issues that impact directly on efforts to disseminate accurate information on the effectiveness of developing interventions that stem from ABA. One of these issues is embedded within the difficulties arising from the transmission of research findings from one culture to another (Dillenburger et al. 2014a, b). It is (unfortunately) customary in Europe, for example, not to involve behaviour analysts in the writing teams of government reports regarding reviews and recommendations of autism interventions (Keenan 2014). A good example is the Linea Guida 21, a guideline on effective treatments for autism recently published by Italian Istituto Superiore di Sanità (ISS 2011), a research branch of the Italian Ministry of Health. This guideline asserts that behavioural interventions are most effective in autism treatment. However, because no behaviour analyst, academic or professional trained in $\mathrm{ABA}$, was on the scientific board that evaluated the research (Moderato 2012), the guideline report contained worrying examples of confusion between the science, procedures, models and protocols for intervention (see below).

Misrepresentations of ABA abound not only in government reports but also in the media and social media (BaronCohen 2014; The Skeptical Advisor, 2014) and even more worryingly in some peer-reviewed journal articles (Cassidy et al. 2007). ABA has suffered from the influence of folk psychology's misrepresentation of Skinner's work (Chiesa 1992; Day 1992; Ruiz 1995; Todd and Morris 1983), and classic propaganda techniques (Gambrill 2012) have been used to chastise those who dare to correct misrepresentation: ...the whole ABA movement appears increasingly more like a cult than a science: there is a charismatic leader, a doctrine, a failure to engage with criticisms, inquisition and denunciation of any who criticise (however mildly), misrepresentation of critics, and proselytising exercises to gain more converts and spread the word. (Jordan 2001, p. 421)

ABA has been mocked (Kaufman 2013), branded controversial (Lambert 2014; Scott 2014), related to post-traumatic stress disorder (PTSD; Research Autism 2014) and attacked for promoting a 'normalisation agenda' (Lambert 2014; Milton 2012). Maurice (1999) captured these absurdities and controversial misrepresentations as follows:

Dozens of pseudo-scientific books and articles out there describe it $[\mathrm{ABA}]$ as child abuse, a squelching of the spirit, a crushing of the soul. Treating the symptoms and not the "root cause," whatever that might be; a denial of the self, cruel, manipulative, dehumanizing, punishing, controlling; etc. etc.

Moreover, even when people do not attack behaviour analysis, they make glaringly ignorant statements about it, like "Oh yes, that's where they do discrete trials for forty hours a week." Or, "behaviour management is for really low functioning kids. (p. 3)"

To highlight the significance of common caricatures of ABA in autism intervention, Fig. 1 offers an accurate, albeit succinct summary of how the scientific method guides decision making in an ABA programme.

\section{Step 1: Select Behaviour to be Analysed}

A decision is made about which behaviours should be analysed, i.e. targeted for change. For younger children with autism, this decision involves the family and professionals working as a team to determine priorities and goals to be achieved. Older children and adults should also be involved, if possible, in decision making about which skills would enhance their quality of life, e.g. the development of social or employment skills.

\section{Step 2: Measure the Behaviour}

As with any science, decisions are made about how to measure the behaviour which defines the goals of an intervention, e.g. is it more important to engage in a behaviour more often (and thus measure frequency) or to engage in a behaviour for longer periods of time (and thus measure duration); or is it important to engage in the behaviour faster (and thus measure interresponse time or latency) or to engage in a behaviour at a steady and consistent pace (and thus measure rate). Measurement is essential for monitoring progress and for tailoring an 
Fig. 1 Five basic steps in using the Scientific Method in ABA (adapted from Reese et al. 1979, p. 34)

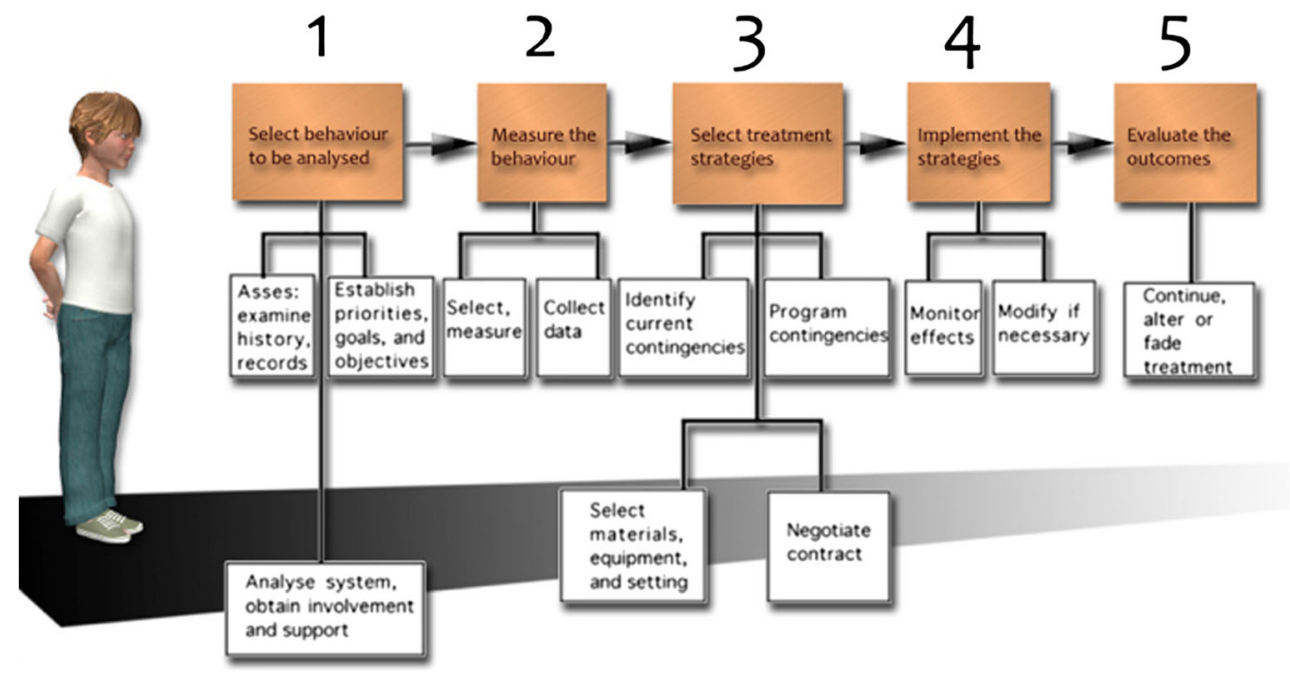

intervention to the needs of an individual. Training in the analysis of behaviour provides skills in the operational definition of all behavioural targets. This skill set provides measurement strategies that bypass misleading issues arising from the use of summary labels and explanatory fictions (Chiesa 1994; Cooper et al. 2013; Moore 2008).

\section{Step 3: Select Treatment Strategies}

Progress is dependent on the appropriate choice of intervention. This in turn depends on the nature of the goals specific to each individual. Interventions in $\mathrm{ABA}$ are based on existing principles of behaviour that have been uncovered by the natural science of behaviour analysis; in other words, they are based on the findings of how behaviour is learned. Behaviour is defined holistically as the interaction between the biological organism and the environment. It is understood that this interaction involves a continuous flow of adaptations and therefore interventions have to remain flexibly attuned to changes as they occur. The intervention strategy, then, depends on individual circumstances and it changes dynamically with behavioural change and progress.

That said, there have been some issues about particular procedures, especially if they included the use of aversives. Wing (1966), for example, recommended a 'smack, a loud firm 'no' or putting the child out of the room' (p. 272) for children with autism. Schopler et al. (1980), who devised a commercial package called Treatment and Education of Autistic and related Communication Handicapped Children (TEACCH), described the use of 'aversive and painful procedures' such as meal deprivation (p.121), 'slaps or spanks on the bottom' (p.121), and 'electric shock, unpleasant tasting or smelling substances' (p.122) as methods that could be used if other methods do not work. Inexplicitly, however, it has been Lovaas who was much more heavily criticised for using these methods than either Wing or Schopler (Webster 2011).
The discussion about the use of aversives should be viewed in historical perspective. In the UK, the 'cane' was used to inflict corporal punishment in mainstream schools for all children, until it was finally outlawed in 1987! In private schools corporal punishment was not banned until as recently as 1999 in England and Wales, 2000 in Scotland, and 2003 in Northern Ireland. Physical punishment of children by their own parents is still not illegal in many parts of the world. This is by no means a justification for the use of aversives, on the contrary (Dillenburger and Keenan 1994; Goupillot and Keenan 1995), but it demonstrates that the use of aversives was not a specific and unique feature of behavioural interventions in the 1960s. Punishment is no more advocated in ABA than elsewhere in modern day society (Sidman 2000; see also ABAI 2014, for a position statement on Restraint and Seclusion).

\section{Step 4: Implement the Strategies}

This involves the application of the chosen intervention strategy, and data collection to monitor whether the goal is being reached. Data collection shows, for example, whether progress is being made towards the goal, even if this progress is slower than anticipated. In ABA, data collection takes place continuously throughout the intervention, not merely at the end.

\section{Step 5: Evaluate the Outcomes}

This is integral to the individual-centred focus of ABA in that it demands adjustments to be made dependent on the progress of the individual when using the selected intervention. At its most basic, if the intervention is not working, then it is adjusted until the targeted change is achieved, i.e. the barriers to quality of life are removed.

The steps described above are simply the application of the scientific method. Even parents who are not specifically 
Fig. 2 Different perspectives of a professional at work. Left panel A surgeon is giving a running commentary on his operation to medical students. Right panel The same commentary is given to parents of the child undergoing the operation
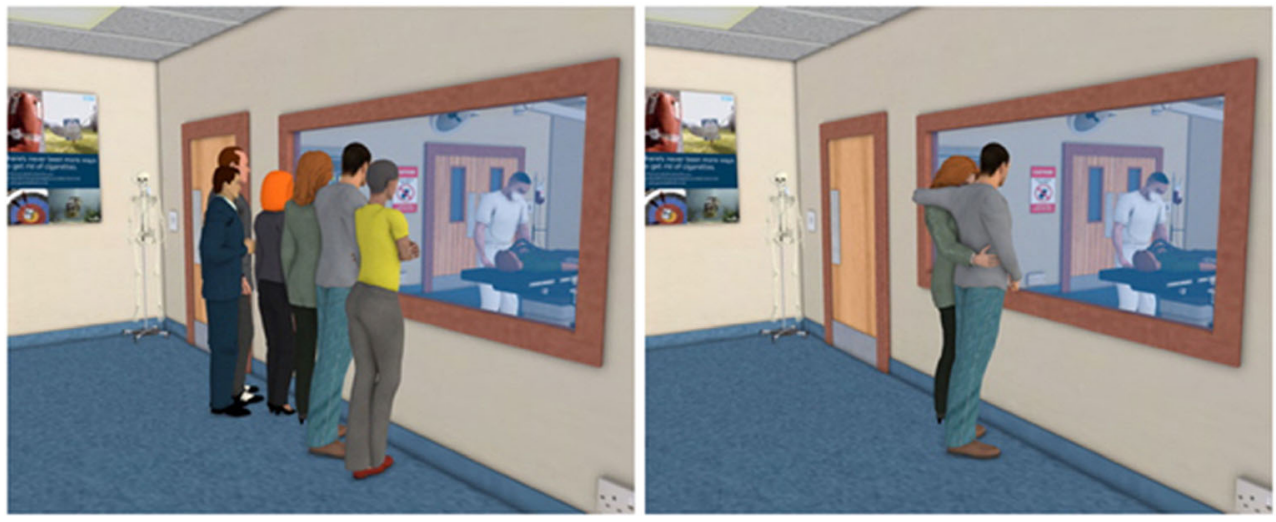

trained in ABA find the steps coherent and 'common sense' (ABA4all 2014). Behaviour analysis simply makes explicit the principles of behaviour that operate implicitly in everyday life (Keenan and Dillenburger 2014). The emphasis here is the word 'analysis': "Such an approach entails far more than changing behaviour. It entails understanding behaviour and the complexity of the interactions between individuals and their environment, particularly their social environment." (Walsh 1997, p. 101). The caricatures and misrepresentations that persist and impede the uptake of an effective science are puzzling.

\section{Communicating the Practices of a Natural Science}

One of the difficulties with understanding the 'real' ABA is the language of the science itself. There are a couple of issues at work here. Figure 2 illustrates one aspect of the problem. The left-hand panel shows a surgeon operating on a child whilst at the same time a group of medical students is watching intently. Imagine that the surgeon is providing a running technical commentary on every incision/decision he makes. He does so to ensure that his students will be able to replicate the operation with the same degree of skill he is showing them.

Now imagine that the parents of the child are watching the surgeon (right-hand panel). The parents and others not trained in a natural science might view the words of the surgeon as overly technical or even cold and uncaring. At issue here is not the skill of the surgeon (the speaker), but the level of understanding of the audience (the listener). This is an unfortunate problem because the surgeon is not a cold-hearted individual and the science that guides the operation is acutely concerned with human welfare and wellbeing. ${ }^{1}$ The problem is one of

\footnotetext{
${ }^{1}$ This example is not meant to imply that a medical model is being promoted. It is merely an example of the problems caused when technical terms from a science are misunderstood by those not trained in that science.
}

how to share sophisticated knowledge and skills with lay people who have not received training in the science.

The same is true for ABA. However, training in the science of ABA to international standards is not available in most European countries (BACB 2014b; Chiesa 2001; STAMPPP 2014). For example, Dillenburger et al. (2014b) noted that professionals who are typically involved in autism diagnosis and treatment (i.e. paediatricians, psychiatrists, social workers, speech and language pathologists, occupational therapists, teachers, as well as clinical and educational psychologists) generally receive very little or no training in autism or ABA during their qualifying training.

It is hardly surprising, therefore, that professionals who are untrained in a natural science of behaviour may come to conclude that they are watching the practices of a coldhearted scientist and do not appreciate the precision and sophistication of the required competencies. Yet, without the skills of the doctor or scientist, and the skills of next generation of students of the science, the intervention is likely to be ineffective (Jacobson et al. 2005).

To some extent, misrepresentation of ABA is to be expected when training is not available. However, there is another more pernicious and subtle way to undermine the potential support by governments for training in ABA in Europe. Keenan et al. (2010) drew attention to the damaging effects of the privatisation of science by behaviour analysts in a context where governments and parents cannot discriminate between specific approaches, packages, commercial products, and the science that lead to their development. For example, the Early Start Denver Model (ESDM), which is now popular in Italy, is based on behaviour-analytic principles. Behaviour analysis is a science, ABA is an applied science or technology, ESDM is one of the many possible models that apply the principles (Moderato et al. 2010a, b). The same is true for Positive Behaviour Support (PBS) and the Picture Exchange Communication System (PECS; Frost and Bondy 2002), both of which are widely supported in the UK and elsewhere in Europe. All kinds of problems arise when commercial interests in the promotion of a package or a 
'product' come into conflict with efforts to ensure that ABA is exalted as the foundation of the package or product.

\section{The State of the Science in Europe}

\section{UK and Ireland}

The historical legacy of 'behaviour modification' without functional assessment or functional analysis (i.e. the rush to implement behaviour change procedures without appropriate analysis of the function of behaviour, Walsh 1997) has resulted in a blinkered view of the true nature of behaviour analysis (Keenan 2004; NAS 2014; NICE 2013), including confusion over how the term 'behaviour' is viewed by behaviour analysts (see comments to Lambert 2014). A good example comes from a major charitable organization, Research Autism, that informs the National Health Service on autism interventions in the UK:

Because there are many different interventions, programmes and techniques used to help individuals with autism which incorporate the principles of applied behaviour analysis it is not possible to provide a ranking for applied behaviour[al] (sic) analysis as a whole. (Research Autism 2014)

The suggestion here that $\mathrm{ABA}$ is simply a collection of procedures/techniques is a theme that is repeated across Europe and has lead to the marginalization of a whole science (Odom et al. 2012), with governments in both N. Ireland and the Republic of Ireland refusing to correct the misinformation on ABA that informs their autism policy (Keenan et al. 2013); in the Republic of Ireland, policies are designed under the umbrella of PBS with no reference to international standards of training in ABA (Health Act 2007).

In marked contrast to the conclusions of Research Autism, Hagopian and Hardesty (2014) provide a comprehensive list of other organisations that were able to make recommendations about ABA. In both parts of Ireland, the predominant view is also that "ABA is simply one of a number of techniques' provided within an eclectic model of service provision (Keenan 2014; McCormack 2014). To complicate matters, the list of techniques includes a serious category mistake (see below) such that ABA and PECS, for example, are each considered techniques:

As it stands, the ABA experts are uniformly of the opinion that what the government provides under the eclectic model is not ABA in any sense of the word. What the department of education is doing is the equivalent of ignoring the advice of heart surgeons on heart surgery and instead taking advice from GPs and dentists. (Irish Election 2014)

ABA remains unrecognised and unsupported by governments and by key agencies providing national guidance and advice (e.g. NICE 2014).

\section{Germany}

In Germany, Applied Behaviour Analysis is neither officially recognised nor supported. The responsibility for the care of individuals with autism lies with both the health and the social care sectors. Diagnosis of ASD and of co-occurring disorders is the responsibility of the health care system, but due to a court decision in 2009, ASD is classified as a static, 'lifelong' condition that does not respond to intervention and therefore does not legally qualify for treatment. As a result, German healthcare (i.e. health insurance) is not obliged to cover autism treatment. In reality, some healthcare funding is available for individual and group programmes for adolescents and adults with high-functioning ASD and Asperger's Syndrome. Intensive programmes for children and individuals with lowfunctioning ASD are not funded, despite the fact that professional medical guidelines recommend behavioural interventions as the only evidence-based interventions (Deutsche Gesellschaft für Kinder- und Jugendpsychiatrie und Psychotherapie 2007).

Where they are available, autism interventions in the health care sector are delivered or supervised by medical or psychological professionals who have recognised qualification in behaviour therapy. The term "autism specific behaviour therapy" (Autismus-spezifische Verhaltenstherapie-AVT) has been used to describe the methods used with individuals with autism. AVT is not the same as ABA and does not meet the quality standards of the Behaviour Analyst Certification Board.

Early or intensive ASD interventions are the responsibility of the social and disability care system. This system is organized on a local level without federal or Länder/State standards. Decisions regarding intervention method, intensity, and staff qualification are made by public servants with administrative qualifications and/or by social workers most of whom have little or no training or experience in the field of ASD.

While there are a small number of autism-specific institutions who deliver behavioural programmes, the majority of these centres prefer an "eclectic" approach, including nonspecific, psychodynamic, and/or complementary and alternative medical interventions that are not evidence-based. The leading parents' advocacy group Autismus Deutschland strongly opposes the focus on evidence-based interventions, in fact, they view them as 'restriction'. However, recently, due to extensive lobbying from experts as well as parent groups, there are some signs of development. Recommendations and guidelines are 
about to be published in some German Länder/States by the social and disability services that are based on evidence in favor of behaviour interventions (Landschaftsverband Rheinland und Westfalen-Lippe 2014).

There are no degree courses in German universities that teach full ABA curricula because a degree in ABA would not be recognised since $\mathrm{ABA}$ is not recognised as a healthcare profession. In addition, curricula in most psychology and medical courses do not prepare students for autism-specific interventions (Dillenburger et al. 2014b).

The University of Applied Sciences in Münster is the only German university that offers undergraduate and postgraduate courses in "autism specific behaviour therapy". These courses are delivered in cooperation and with the support of international partners. The leading association of behavioural psychotherapists (Deutsche Gesellschaft für Verhaltenstherapie; DGVT) offer a (voluntary) postgraduate staff qualification in "autism therapy" with a strong behavioural focus.

The Association for Behaviour Analysis Deutschland (ABA-D) is a Chapter of the Association for Behaviour Analysis - International. This Chapter was set up in 2011 by eight ABA professionals, some of whom were trained abroad, others who were psychological or psychiatric staff with extensive experience in the field. There is $1 \mathrm{BCaBA}, 10 \mathrm{BCBAs}$, and 3 BCBA-Ds in Germany. Early behavioural interventions and parent training are delivered by a small number of agencies under a variety of different supervision and funding arrangements, some of these are not-for-profit others are private enterprises.

Statutory education in Germany is governed by Länder/ States and therefore the school situation for children with autism varies considerably. For the most part, educational staff and teachers tend to reject behavioural interventions, whereas special needs education staff are more interested in ABA.

In conclusion, Germany could still be considered a 'developing country' in terms of ABA. Progress is slow and the potential of the majority of individuals with ASD remains untapped and their quality of life and chances for independent living remain unnecessarily limited.

\section{Greece}

In Greece, the first BCBA to offer ABA-based services to families of children with ASD appeared on the BACB registry in 2009, and the situation has changed little since then. Worryingly, an internet search reveals that there is an abundance of unqualified professionals offering $\mathrm{ABA}$ as one option within an eclectic model. The paucity and lack of quality of behaviour-analytic services feeds the debate about whether ABA-based treatment is humane/ethical, whether outcomes are generalized, or whether different individual needs are taken into account. This situation represents a major obstacle in helping children with ASD reach their full potential because it misleads parents, naïve professionals and the health system overall.

The difficulties currently experienced by the Greek economy place a further burden on families, who in 2011 received a maximum of $527 €$ per month by the state for the care of the family member with severe disability (requirement of at least $67 \%$ of disability) (Joint Ministerial Decision $\Gamma 4 / \Phi .12 /$ oเk.1930/1982; Joint Ministerial Decision $\Pi 3 \alpha / \Phi .18 /$ Г.П.оск. 63731/2008). In a 2013 law, however, the requirement for receiving the highest amount of $527 €$ per month was restricted only to individuals with at least $80 \%$ of disability (Joint Ministerial Decision П3 $\alpha / \Phi .18 / Г . П . о с к . ~ 63731 / 2013$ ). These changes in legislation together with increased unemployment and decreased salaries have undoubtedly limited access to effective treatment.

Interestingly, a law (Law 3699/2008) that in its very first paragraph explicitly sets the state responsible for

safe-guarding and improving the mandatory character of special education as an integral part of mandatory, free of charge and public education and for caring for the provision of free public special education and training to individuals with disabilities of any age and for all the stages and education levels. The state also commits to provide all citizens with disability and proven special education need with equal opportunities for full participation and contribution to the society, independent living, economic self-sufficiency and autonomy, full guarantee of their rights to education and social as well as professional inclusion.

does not include any mention on how scientific evidence will lead the pathway to meeting these aims for individuals with disabilities and autism more specifically. Given that legislation in Greece does not accommodate ASD separately, but instead describes the necessary education and treatment for all children with special needs, ABA is not even mentioned in any official documents. Instead, traditional eclectic interventions delivered by psychiatrists, psychologists, speech and language therapists, special educators and occupational therapists are often prescribed and partly funded by the public health system in educational or home settings (Ministry of Interior et al. 2007). Official documents repeatedly mention "early intervention" and "inclusion" as goals but these are left to be achieved by state teachers who are unlikely to have had any training in the science of ABA (Law 3699/2008).

Notwithstanding this devastating picture, the first comprehensive textbook on behaviour analysis in the Greek language was published by Mellon in 2005; in 2009, the conference of the European Association for Behaviour Analysis was held in Greece, and thanks to the efforts of a small number of behaviour analysts, both academics and clinicians, there has been an increase in the number of students studying ABA at 
undergraduate and postgraduate level. There has also been a corresponding increase in the number of professionals who receive supervision by a BCBA or BCBA-D, and an increase in the number of families and professionals who can now access accurate information about the science (e.g. Dounavi 2013). Although there is a long and difficult journey ahead, there is hope that knowledge about the applications of behaviour analysis will eventually reach the public and be incorporated in a public accessible for all health and education system.

Iceland

In Iceland, ABA-based intervention for preschoolers with ASD started as a research project in 1995, where a group of children participated in a multi-site Lovaas replication study (Jónsdóttir and Eikeseth 2000). In 2000, a decision was taken at the State Diagnostic and Counselling Centre (SDCC), an institution that serves the whole country, to inform parents of newly diagnosed young children about this option in addition to the prevailing eclectic approach. Today, more than half of these parents choose an ABA programme and attend courses and workshops provided by the SDCC. Legislation provides young children with ASD, as well as other children with special needs, the rights to services at the preschool level under the guidance of specialists (The Pre-School Act, no. 90/2008). Provisions are made for special education for a specific number of hours per week depending on the child's needs and condition. There are, however, no official guidelines or recommendations available regarding teaching approaches, giving those who are responsible for providing the services in the schools the freedom to follow their own preferences.

The uptake of ABA has not been painless and is still met with scepticism by some service providers, who refuse to accommodate it due to ideological reasons, and who still equate it with dog training. Misinformation about $\mathrm{ABA}$ is not surprising when considering the education and training of teachers and other professionals who are directly involved with teaching children with autism. A brief survey conducted in 2013 on the content of their education and training at the University of Iceland, indicated that those working with children with special educational needs have not been provided with a theoretical background in behaviour analysis, nor training in the specialized and evidence-based methods that are needed to teach effectively (Sigurdardóttir et al. 2013).

There are five BCBAs in Iceland, all educated in the USA, and three of them supervise programmes for children with ASD for only part of their time. In addition, there are a handful of supervisors with some training and extensive experience in behaviour analysis, but without certification in that field. Although the services have suffered from too few qualified individuals who can meet increasing requests from parents for an ABA-based programme, there is a reason for some optimism.
A master's programme has recently been established at Reykjavik University that offers the courses required for BCBA certification. An increasing number of school principals, both at the pre- and primary school level, support the uptake of ABA for students with ASD in their schools, even though most of those who provide direct services (teachers and trainers) are still not receiving adequate training and supervised experience. One school is collaborating with credentialed ABA consultants from USA, and a preschool in Reykjavík is now aiming to be recognised as a specialist in ABA-based intervention with plans to collaborate with universities and experts in the field, and secure supervision from BCBAs. This project holds the potential to become a training centre for those who want to pursue certification in behaviour analysis, as well serving as a model for other schools.

\section{Italy}

In Italy the welfare system provides support and services free of charge to children with disabilities and their families, but its application depends on the regulations of each region. Due to the lack of any centralised autism resource or diagnostic centre, like those that exist for other conditions (e.g. oncology) the waiting list to be assessed and then potentially receive a diagnosis from a child psychiatry department is long, typically 6 months to 1 year or more. Following a diagnosis of ASD, the child is generally assigned to an eclectic treatment for one or two sessions a week with a physical/psychomotor therapist and a speech and language therapist. With very few exceptions, a BCBA, or someone with equivalent qualifications and experience, is not available in the public health service. This means that it falls to the parents, once they have more information about evidence-based treatments (often via some unofficial or informal way), to find and recruit a private ABA service provider if that is what they decide they want. The cost of doing this varies and is partially (20-40\%) reimbursed in some regions (like Veneto and Puglia) according to the different regional health systems. The criteria for acknowledging who is to deliver ABA-based interventions are also very loose and confusing.

As an alternative to obtaining behaviourally based interventions, the family can take the child to a habilitation centre or private clinic, very few of which deliver true ABA-based treatments (i.e. treatments delivered by appropriately trained and credentialed professionals). The interventions are carried out in the centre, and should follow the Linea Guida 21 mentioned above. Unfortunately, the Italian parliament has no mechanism for regulating the field and ensuring that every centre and department follows the published guidelines and provide only interventions based on scientific evidence and best practice. The lack of regulation allows methods such as 'facilitated communication' to survive in some parts of the country. In 2011, a pilot project 
was started by two organisations-IESCUM and FOBAPAnfas (a historical association for disabled people), funded by the regional government, to provide ABA interventions, for children from age 2-16 years. The interventions comprised for 2-h sessions plus $2 \mathrm{~h}$ for parent/teacher training for children aged 2-7; two 2-h sessions plus $2 \mathrm{~h}$ for parent/ teacher training for children aged $7-12$. The results are very encouraging in terms of effectiveness with a reasonably limited use of human resources. Sustainability of the interventions is, and will continue to be, one of the main problems to face once people ask for early or intensive ASD interventions. ${ }^{2}$

In parallel with this pilot project, children are included in regular preschool class, as mandated by Italian laws for inclusion, with a special support teacher to work with the child. This is a great opportunity for the development of the child, especially if the special support teacher is trained in the principles of behaviour analysis and the whole school collaborates with the $\mathrm{ABA}$ professionals. The acceptance of $\mathrm{ABA}$ within mainstream pedagogy, however, is very low, with the situation somewhat better within the field of special education. One of the reasons for this state of affairs is the negative side effect of the publication of Linea Guida 21.

Due to the increased demand of EIBI and the lack of available certified ABA professionals (there are only about 40 in Italy), some private agencies organize short courses, with the promise of training people as, for example, 'ABAVB' consultants. This is, of course, false advertising. What is even worse, though, is that some state and private universities advertise Master programmes in ABA where the science of behaviour analysis has no support, and EIBI disappears into an ocean of eclectic interventions.

\section{The Netherlands}

On average, children in the Netherlands are diagnosed with ASD from the age of 5 years (Nederlandse Vereniging voor Autisme 2008; Peters-Scheffer et al. 2014). As a consequence, these children receive treatment much later than is recommended (Warren et al. 2011). Some children with ASD enrol in special classes (about $23 \%$ in less intensive special education and $35 \%$ in intensive special education), whilst others (about 39\%) attend a class where there are other children with developmental disabilities such as Down Syndrome, learning disabilities and/or an intellectual disability and/or behavioural challenges (Nederlandse Vereniging voor Autisme 2008). Due to recent changes in educational policy in the Netherlands (Rijksoverheid Nederland 2013; Dienst Uitvoering Onderwijs 2010), children with ASD who have an average or higher

\footnotetext{
${ }^{2}$ Sometimes packaged as Early Intensive Behavioural Intervention (EIBI)
}

intellectual and linguistic ability are increasingly attending regular education. It is uncertain to what extent school placement scores predict later social and economic functioning for children with ASD, however, there is some evidence that school attendance and increased social interaction with peers and adult educators provides them with more opportunities to prepare for the future (Eikeseth 2009; Matson and Smith 2008; Peters-Scheffer et al. 2011; Reichow and Wolery 2009; Smith et al. 2000). Currently, this outlook is rather bleak in terms of employment, housing and relationships (Howlin et al. 2014; Parsons et al 2013).

Dutch teachers are increasingly confronted with a three-fold set of demands: (1) increasing number of pupils in their classes (currently, on average 30); (2) increasing heterogeneity or diversity of the pupil population, including behaviour problems and developmental disabilities; (3) increasing responsibility of educational and care provisions for all pupils as a result of Passed Onderwijs/Inclusive Education, which is currently being implemented (Dienst Uitvoering Onderwijs 2010). In other words, teachers are expected to cater for the educational and care needs of all pupils in their class. However, teachers are only sparsely equipped in terms of the appropriate training to meet these expectations and to provide adequate and sufficient support for pupils with special educational needs, including those with ASD (Neidt and Schenk 2012). In addition, other barriers to implementation of evidence-based practice informed by ABA include poorly developed interventions that have limited empirical evidence for their effectiveness and implementation of ABA-based interventions by professionals who have not received appropriate training or supervised experience. To date, no higher education and/or training is available for those interested in ABA in the Netherlands. To complicate matters, Dutch parents of children with ASD are only informed about psycho-educational and pharmacological treatment options following diagnosis (Neidt and Schenk 2012; Schothorst et al. 2009), and receive limited information regarding evidence-based interventions in other countries and continents (Peters-Scheffer 2013). A recent Dutch guide for the multidisciplinary diagnosis and treatment of adults with ASD (Schothorst et al. 2009) claimed that there is no evidence that outcomes for people with ASD in the long term are significantly better following training programmes during childhood (Kan et al. 2013).

Since few children in the Netherlands are engaged in EIBI programmes, it will take many years before professional educators and parents are properly informed about ABA-based intervention alternatives. The knock-on effect, of course, is that given the shortage of appropriately educated and trained professionals, it will take some time before large-scale applied research within school settings can demonstrate that ABAbased interventions are effective, regardless of whether these are implemented at preschool age or before - as long as implementation is done competently and completely. 
Spain

The first generation of behaviour analysts in Spain is still active in academia (Bayés 2003). During the 1970s, they authored the first behaviour-analytic studies to be conducted in the country (e.g. Bayés 1972) and promoted Spanish translations of some classic behavioural texts (e.g. Skinner 1952/1977, 1974/1977). Interestingly, autism services developed somewhat independently from the university setting, where the experimental analysis of behaviour and clinical applications for adults and typical children received more attention (e.g. Ardila 1998; Froján-Parga 1998; Luciano 1996; Pellon and Blackman 1987; see also Cruz 1984). Applied research with children with autism developed significantly later and is still significantly underrepresented.

The first applied programme for children with ASD offering behavioural services was the Fundación Planeta Imaginario, established in Barcelona in an attempt to provide a further replication of the Lovaas (1987) study. The programme continues to be one of the leading ABA services in the country, though there are some 10 applied programmes and $1 \mathrm{BCaBA}$ and $8 \mathrm{BCBAs}$.

The Association of Behaviour Analysis Spain (ABA Spain 2014) has been critical in facilitating (a) the translation of reference materials into Spanish (e.g. Miltenberger 2013), (b) the translation of BACB exams into Spanish, (c) the recognition of the BACB credentials by the Spanish Colegio de Psicólogos, and (d) the development of a consortium of applied programmes offering practicum placements in Spain and the USA (Virues-Ortega et al. 2009).

Yet, in spite of these promising signs, the situation for families of children with autism is somewhat disheartening. Behaviour analysts work with less than $1 \%$ of the 7000 new cases of autism diagnosed every year in Spain. ${ }^{3}$

ABA-based services are not covered by Spanish health or education services. Whilst there are a few documented exceptions where a court has mandated that a particular individual should receive intensive behavioural intervention, services are almost always paid for by the families privately. A few creative alternatives have been tried in recent years. For example, the Escuelita de Ilusiones school in the Canary Islands (fundailusiones.es) has transitioned from a not-for-profit project into an official special education school. The school is government-funded although run privately.

Greater presence in academia and greater advocacy in the public arena continue to be important challenges in the agenda for behaviour analysts in Spain.

\footnotetext{
${ }^{3}$ Estimation based on Center for Disease Control prevalence rates interpolated to the Spanish child population for 2010; sources: CDC and INE.
}

Sweden

In Sweden, the welfare system provides supports and services free of charge on a needs basis to children with disabilities and their families. Following a diagnosis of ASD, the child and parents are assigned to a multi-professional habilitation team (health care system) which may comprise a psychologist, special educator, speech language therapist, social worker, occupational therapist and/or physical therapist, any of whom may or may not also be a BCBA or have equivalent training. In parallel with this, the preschool in which the child is enrolled obtains central funding from the local education authority to employ a para-professional (trainer) to work with the child (see Eikeseth et al. 2012).

In order to obtain behaviourally based interventions (focused or comprehensive), the family, child and trainer travel to the habilitation center on a regular basis to obtain supervision, review goals, and make decisions about the implementation of new interventions. The interventions, however, are carried out in the preschools and home, and it is extremely rare that habilitation specialists are actually able to make onsite treatment fidelity visits. It is within the sphere between habilitation and preschool that the complex mechanisms within a dual service system come into play. For example, the National Health Care Law (Hälso och sjukvårdslagen 1982: 763) highlights the importance of personnel within the health care system providing interventions based on scientific evidence and best practice. The Swedish habilitation administrators recommend early (as soon as ASD is identified), comprehensive and intensive, behavioural interventions (Bromark and Granat 2012). However, whilst evidence and best practice are mentioned in the Swedish Education Act (Skollagen 2010:800), there is no definition of these terms and no contingencies for preschools or schools not providing evidencebased interventions. Parents not receiving evidenced-based interventions have no recourse through the legal system and neither formal nor informal mediation is mentioned by the School Inspection or the School Board of Appeal as an alternative to adjudication. Lack of guidelines might also explain in part how methods such as 'facilitated communication' surface in some parts of Sweden (see Dagens 2014).

There are also philosophical perspectives engrained in the Swedish educational system that further distance the acceptance of ABA from mainstream pedagogy. For example, in an article in Pedagogiska Magasinet (Englund and Engstränd 2011), a teacher union magazine with approximately 200,000 subscribers, there was an illustration depicting children as puppets, helplessly controlled by a 'behaviour modifier'. This illustration won the best illustration prize in 2012. The article warns against the 'Return of Behaviourism' and argued that behaviour modification may have a place in psychotherapies for phobias but not within the educational system. It was said that behaviour 
modification deviates from current pedagogical as well as developmental theories where there is an emphasis on mutual respect for the relationship between educator and student/child in terms of the importance of learning and development. Also, there was doubt whether programmes from the 'American context' with different historical and relationship ideologies can be automatically be transferred to a Swedish context. The Swedish National Curricula for preschool highlights the importance of democracy, every child's right to express their own opinion, and make choices, and that preschool should prepare all children for lifelong learning, be enjoyable, safe, and provide a rich learning environment which is built on the child's experiences, interests, needs and opinion, and free of any kind discriminatory influences (Lpöf 1998 revised 2010). Whilst there can be little argument against the goals in the text, there are differing epistemological traditions between the health care system (e.g. habilitation) and municipalities (e.g. preschools) on how to build on a child's experiences, interests, opinions, etc. Possibly reflecting the effects of epistemological discrepancies at the heart of this dualistic system, Zakirova Engstrand and Roll-Pettersson (2012), a pilot study concerning preschool teachers attitudes to the inclusion of children with autism in a middle-sized municipality, found that participants showed neutral attitudes towards inclusive practices and only $43 \%$ reported that supports for the child with autism were based on ABA. In addition, the average number of hours per week in which they worked one-to-one with the child was 2.56. It appears, therefore, that the epistemological and philosophical gulf between these sectors is in need of bridging, which should minimally include recognition of ABA in mainstream pedagogy and special pedagogy (see Roll-Pettersson and Ala i'Rosales 2009; Käck et al. 2014). In light of parents' lack of a legal mandate, there is also a need for inter-organisational contractual agreements guaranteeing children with autism the right to appropriate and individualized ABA interventions implemented with integrity.

Despite these barriers, several behaviour-analytic textbooks have been published in Swedish (Eikeseth and Svartdal 2013; Karlsson 2010; Ramnerö and Törneke 2013) and Stockholm University offers an inter-departmental graduate level, BACB approved course sequence in behaviour analysis where half of the sequence is given through the Department of Special Education and half through the Department of Psychology (Roll-Pettersson et al. 2010). To date, approximately 250 psychologists, special educators, social workers, educators and speech language pathologist employed by either habilitation centres or municipalities have taken these courses. A spin-off effect of the heterogeneity of student backgrounds and the inter-departmental collaboration has resulted in new and innovative partnerships between these organisations (Roll-Pettersson \& Olsson 2015).

\section{Ethics}

Notwithstanding the differences in philosophy, pedagogy and update of behaviour-analytic services across Europe, the universal and explicit values of ABA center around the enhancement of socially relevant and culturally valued quality of life (Baer et al. 1969). The targets for interventions are those behaviours that constitute barriers affecting the quality of life for individuals, families, or communities, including issues within families, relationships, social life, education, health, employment, leisure activities and relaxation (Cooper et al. 2013).

There is nothing remarkable about the selection of these targets; they include the same goals and aspirations most people have for themselves and for their loved ones. The key issue is that without a repertoire of appropriate behaviour, these goals and targets remain out of reach (Baer 2005). The focus of ABA is to help facilitate behavioural growth and skill development to enhance the quality of life. ABA operates within a natural science perspective and using the scientific method applied to individuals, it offers the necessary analysis and technology to achieve the goals associated with agreed values. This is not the same as promoting a normalization agenda, something that is integral to PBS (Mulick and Butter 2005).

Training in ABA also adheres to clearly defined ethical standards (BACB 2014a). Issues concerned with professional ethics, though, often extend beyond the actual practice of a science. For example, in relation to representation on review panels, a guiding principle in most professions is exemplified by this statement from another scientific body:

As a general rule, in matters concerning physics, the Institute of Physics in Ireland would seek to have appropriately qualified physicists represented on any review panel which might be reporting on 'findings from physics'. (personal communication, Institute of Physics in Ireland, May, 2012)

Similar concerns about professional competence are enshrined in ethical standards of other professional bodies such as Social Work, Psychology, Speech and Language Therapy, Occupational Therapy, all of which usually have an input in policy and practice decisions in relation to autism treatment.

Unfortunately, as we have seen above, across Europe, this ethical imperative has been routinely flouted when it comes to the science and profession of Applied Behaviour Analysis (see ethical guidelines from BACB 2014a). As another example, in both Northern Ireland and in the Republic of Ireland to date, none of the huge numbers of the autism reports or strategy documents have included any professionally qualified representative of ABA (Keenan 2014; McCormack 2014; Behaviour Analysis in Ireland 2013). Consequently, due to the Dunning-Kruger effect, misinformation and the associated 
caricatures of $\mathrm{ABA}$ have formed the basis of government strategies and policies (Dillenburger et al. 2014a).

\section{Category Mistake and Evidence Base}

A common mistake is the confusion between ABA (the science) with methods derived from ABA. When conducting reviews on the effectiveness of particular methods or procedures, it is important that there is clarity on the distinction between procedures or commercial products and the science from which they have been derived. This is a complicated issue for those not adequately trained in the science, and the ethical guidelines mentioned above are particularly relevant here. Figure 3 was designed to help demonstrate such a category mistake (Cheisa 2005).

When ABA is correctly described, discussions about the evidence for ABA take on a different dimension. Take, for example, the argument that there are no randomised control trials (RCTs) of ABA and, therefore, the lack of scientific evidence means that ABA cannot be recommended. The National Institute for Clinical Excellence (NICE), in their response to the consultation for guidelines for the management of children with autism concluded the following:

In the review of evidence, the Guideline Development Group found no evidence to support ABA, and therefore could not make a recommendation about it (NICE 2013).

Unfortunately, there was not a single BCBA (or anyone else who could have described themselves as a behaviour analyst) on the NICE team who could have corrected this conclusion and NICE ignored protestations to the contrary! Certainly, it makes sense to assess treatment packages that make claims as to their effectiveness (Smith 2013), but it is disingenuous to obfuscate the distinction between treatment packages and the science from which these packages have been developed.

There are no RCTs to justify the general use of Speech and Language Therapy, Medicine, Occupational Therapy, or Clinical Psychology. Clearly, RCTs are not appropriate for the assessment of whole disciplines (Keenan and Dillenburger 2011) and it would be a mistake to conclude that because there are no RCTs these disciplines can never be recommended. It is a mistake to suggest that Speech and Language Therapy, Occupational Therapy, Medicine, or Clinical Psychology are each discrete treatments. Yet, politicians are frequently informed that ABA represents a 'one-size-fits-all' approach (Dillenburger et al. 2014a, b), and they consequently conclude that because each child with autism is different ABA cannot be recommended (NICE 2013). If this mistake was repeated with medical science, the conclusion would be that since the needs of each individual are different, no 'one thing' like medical science should be recommended to address these differing needs.

Contrast this conclusion with the practice of the science as discussed with respect to Fig. 1. It really is a very serious state of affairs when professionals misinform policy makers about a science; that is why adherence to normal ethical standards is so important. The misinformation on ABA has been so pervasive in Northern Ireland, that a previous Minister of Education even described ABA as a 'commercial product' (Ruane 2009).

It is now possible to reliably diagnose autism much earlier and prevalence is estimated to be as high as $2 \%$ of children (CDC 2013; DHSSPS 2014). As these children grow up, it is important that debates based on misinformation do not waste valuable resources that should be used to support individuals with ASD. In Europe, the mischaracterization of a science that can effectively address the pertinent issues has serious consequences for parents and their children. Why shouldn't parents and professionals be trained according to the model outlined

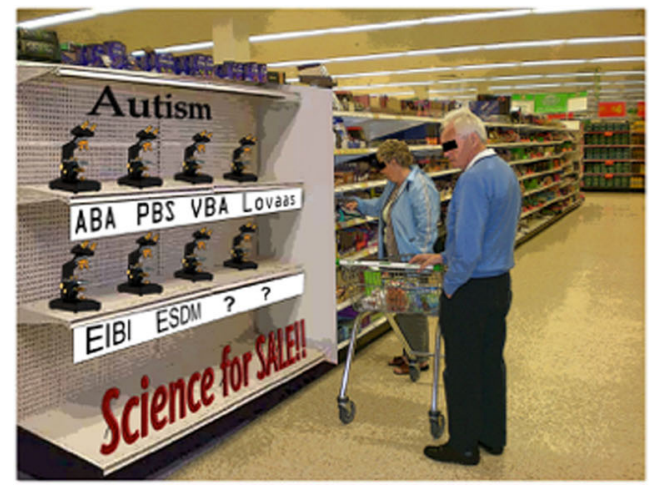

Fig. 3 A classic category mistake. Left-hand panel Applied Behaviour Analysis $(A B A)$ is wrongly put on the same 'shelf' as a range of discrete methods, packages, or products, such as Positive Behavior Support $(P B S)$, the Verbal Behaviour Approach $(V B A)$, Lovaas, Early Intensive Behavioural Intervention (EIBI), and Early Start Denver Model (ESDM); PECS could also be added to replace the "?" on the bottom shelf. This

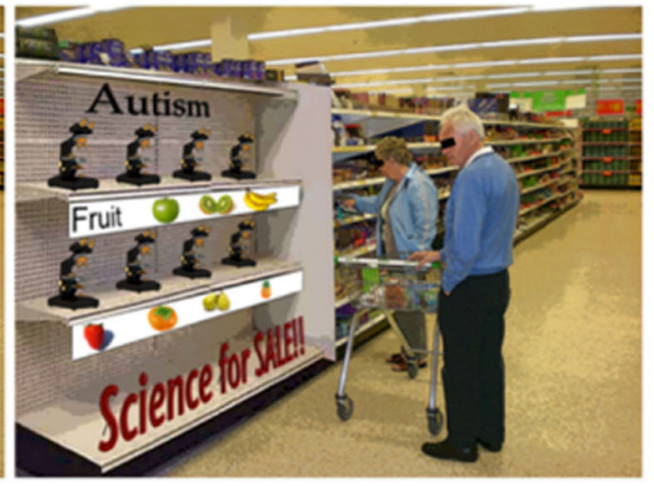

arrangement is inaccurate because ABA is the name of the higher-level category from which these methods are derived. Right-hand panel As a corollary to the mistake on the left-hand panel, 'Fruit' is wrongly placed on the same 'shelf' as apples, oranges, and pears etc., where the inaccuracy is exemplified because fruit is the name of the higher-level category to which the other items belong 
in Fig. 1? This is the question that parents have been putting to governments in their own countries (ABA4all 2014; Unumb 2013; Medicare for Autism Now 2014). ABA is the basis of evidence-based practice par excellence and the outcomes achieved by skilled professionals explain the proliferation of requests by parents and other professionals for access to this science and the appropriate trained and credentialed individuals that practice it worldwide. Unfortunately, straw man arguments about behaviourism (e.g. Milton 2012; see Moore $(1981,1985,2001,2008)$ for an overview of B. F. Skinner's critique of methodological behaviourism) are preventing the light from the application of a science of behaviour (Heward 2003) reaching those who might benefit from its findings.

\section{References}

ABA Spain. (2014). Service directory and collaborators. Retrieved Nov. 24, 2014, from www.aba-elearning.com.

ABA4All. (2014). Community. Retrieved from the Web 06/07/2014. www.facebook.com/ABAforallchildren?fref=ts.

ABAI (2014). The association for behavior analysis international position statement on restraint and seclusion. Retrieved from the Web 06/07/ 2014. http://www.ncbi.nlm.nih.gov/pmc/articles/PMC3089400/.

Anagnostou, E., Zwaigenbaum, L., Szatmari, P., Fombonne, E., Fernandez, B. A., Woodbury-Smith, M., Brian, J., Bryson, S., Smith, I. M., Drmic, I., Buchanan, J. A., Roberts, W., \& Scherer, S. W. (2014). Autism spectrum disorder: advances in evidence-based practice. Canadian Medical Association Journal, 186, 509-519.

Anderson, S. R., \& Romanczyck, R. G. (1999). Early intervention for young children with autism: continuum-based behavioral models. Journal of the Association for Persons with Severe Handicaps, 24, $162-173$.

Ardila, R. (Ed.). (1998). Manual de análisis experimental del comportamiento [Handbook of experimental behavior analysis]. Madrid: Biblioteca Nueva.

Autism Speaks (2014). Nebraska Becomes 36th state to require autism coverage. Retrieved from the Web 27/04/2014 www.autismspeaks. org/advocacy/advocacy-news/nebraska-becomes-36th-staterequire-autism-coverage.

Autism Society Canada (2010). Behavior-based programs. Retrieved from the Web 27/04/2014 www.autismsocietycanada.ca/index. php?option $=$ com_content $\&$ view $=$ article $\& i d=24 \&$ Itemid $=$ $57 \&$ lang $=$ en.

Baer, D. M. (2005). Letters to a lawyer. In W. L. Heward, T. E. Heron, N. A. Neef, S. M. Peterson, D. M. Sainato, G. Cartledge, R. Gardner III, L. D. Peterson, S. B. Hersh, \& J. C. Dardig (Eds.), Focus on behavior analysis in education: Achievements, challenges, and opportunities (pp. 3-30). Upper Saddle River: Pearson.

Baer, D. M., Wolf, M. M., \& Risley, T. R. (1969). Some current dimensions of applied behavior analysis. Journal of Applied Behavior Analysis, 1, 91-97.

Baird, G. (2014). Commentary: Diverging trajectories from a similar starting point: the outcome in adults whose autism was diagnosed in childhood - reflections on Howlin et al. (2013). Journal of Child Psychology and Psychiatry, 55(1), 59-60.

Baron-Cohen, S. (2014). What scientific idea is ready for retirement? Radical Behaviorism. Retrieved from the Web 06/07/2014 http:// edge.org/response-detail/25473.
Bayés, R. (1972). Utilización de tórtolas en el laboratorio operante [Using turtle doves in the operant lab]. Revista Latinoamericana de Psicología, 4, 227-234.

Bayés, R. (2003). Introducción de la obra de B. F. Skinner [Dissemination of B. F. Skinner works]. Revista de Historia de la Psicología, 24, 301-316.

Behavior Analyst Certification Board (BACB; 2014a). BACB Guidelines for responsible conduct for behavior analysts. Retrieved from the Web 27/04/2014 www.bacb.com/index.php?page $=57$.

Behavior Analyst Certification Board (BACB; 2014b). Approved University Training across the world. Retrieved from the Web 27/ 04/2014 http://www.bacb.com/index.php?page=100358

Bromark, G., \& Granat, T. (2012). Rekommendationer reviderad och uppdaterad ur rapporten Mångsidiga intensiva insatser för barn med autism i förskoleålder. [Recommendations revised and updated from the report Comprehensive intensive treatments for preschool children with autism]. Föreningen Sveriges Habiliteringschefer.

Buescher, A.V.S., Cidav, Z., Knapp, M., \& Mandell, D.S. (2014). Costs of autism spectrum disorders in the United Kingdom and the United States Jama Pediatrics, online. ISSN 2168-6203.

Cassidy, A., McConkey, R., Truesdale-Kennedy, M., \& Slevin, E. (2007). Preschoolers with autism spectrum disorders: the impact on families and the supports available to them. Early Child Development and Care, 178, 115-128.

Centers for Disease Control and Prevention (CDC; 2013) Data \& Statistics: Prevalence. Retrieved from the Web 27/04/2014 www. cdc.gov/ncbddd/autism/data.html.

Cheisa, M. (2005). ABA is not 'A therapy for Autism'. In M. Keenan, M. Henderson, K. P. Kerr, \& K. Dillenburger (Eds.), Applied Behaviour Analysis and autism: building a future together. London: Kingsley.

Chiesa, M. (1992). Radical behaviorism and scientific frameworks. American psychologist, 47, 1287-1311. http://dx.doi.org/10.1037/ 0003-066X.47.11.1287.

Chiesa, M. (1994). Radical behaviorism: the philosophy and the science. Boston: Authors Cooperative.

Chiesa, M. (2001). A voice on autism from Europe: a review of Parents' Education as Autism Therapists, Edited by Keenan, Kerr, and Dillenburger. The Behavior Analyst, 24, 101-105.

Cooper, J. O., Heron, T. E., \& Heward, W. L. (2013). Applied behavior analysis (2nd ed.). Harlow: Pearson Education.

Cruz, J. (1984). Breve historia de la modificación y terapia de conducta en España [Brief history of behavior modification and behavior therapy in Spain]. Anuario de Psicología, (30-31), 7-30. Retrieved from the Web 24/11/2014 http://www.raco.cat/index.php/AnuarioPsicologia/ article/view/64522/88353.

Dagens Nyheter (2014, July 20) Skolor använder omstridd metod för autistiska barn [Schools use controversial method for autististic children]. Retrived from the Web 24/11/2014 http://www.dn.se/nyheter/ sverige/skolor-anvander-omstridd-metod-for-autistiska-barn/.

Day, W. (1992). On the difference between radical and methodological behaviorism. In S. Leigland (Ed.), Radical behaviorism: Willard Day on psychology and philosophy (pp. 61-71). Reno: Context Press.

Department of Health, Social Services and Public Safety (DHSSPS; (2014). The estimated prevalence of autism in school aged children in Northern Ireland. Belfast: Community Information Branch, Department of Health, Social Services and Public Safety.

Deutsche Gesellschaft für Kinder- und Jugendpsychiatrie und Psychotherapie (Eds.; 2007): Leitlinien zur Diagnostik und Therapie von psychischen Störungen im Säuglings-, Kindes- und Jugendalter. Tief greifende Entwicklungsstörungen (F 84) in: Deutscher Ärzte-Verlag, 3. überarbeitete Auflage,, S. 225 - 237

Dienst Uitvoering Onderwijs (2010). Factsheet Passend Onderwijs November 2010 [Factsheet Appropriate Education November 2010]. Retrieved from the Web 24/11/2014 www.passendonderwijs.nl. 
Dillenburger, K. (2014). Evidence-based management and intervention for autism spectrum disorders. In M. Fitzgerald (Ed.), Autism (1st ed.). Intech.

Dillenburger, K. \& Keenan, M. (1994). The psychology of smacking children: The dangers of misguided and outdated applications of psychological principles. The Irish Psychologist, January.

Dillenburger, K., Keenan, M., Doherty, A., Byrne, T., \& Gallagher, S. (2010). Living with children diagnosed with autistic spectrum disorder: parental and professional views. British Journal of Special Education, 37(1), 13-23. doi:10.1111/j.1467-8578. 2010.00455.x.

Dillenburger, K., McKerr, L., \& Jordan, J. A. (2014a). Lost in translation: public policies, evidence-based practice, and Autism Spectrum Disorder. International Journal of Disability, Development and Education, 61, 134-151.

Dillenburger, K., Röttgers, H-R., Dounavi, K., Sparkman, C., Keenan, M. Thyer, B., \& Nikopolous, C. (2014b) Multidisciplinary teamwork in autism: Can one size fit all? The Australian Educational and Developmental Psychologist, 1-16. http://dx.doi.org/10.1017/edp. 2014.13.

Dounavi, K. (2013). Teach me how to speak: Language development in children with Autism. Panteion University of Social and Political Sciences. Keynote speaker in the 1st Conference of the Hellenic Community for Behavior Analysis. Retrieved from the Web 22/09/ 2014 at https://www.youtube.com/watch? $\mathrm{v}=\mathrm{Nd} 7 \mathrm{tFcf1} \mathrm{IvU}$.

Eikeseth, S. (2009). Outcome of comprehensive psycho-educational interventions for young children with autism. Research in Developmental Disabilities, 30(1), 158-178.

Eikeseth, S., \& Svartdal, F. (2013). Tillämpad beteendeanalys: teori och praktik. Stockholm: Studentlitteratur.

Eikeseth, S., Klintwall, L., Jahr, E., \& Karlsson, P. (2012). Outcome for children with autism receiving early and intensive behavioral intervention in mainstream preschool and kindergarten setting. Research in Autism Spectrum Disorders, 6(2), 829-835.

Englund, T., \& Engstränd, I. (2011). Behaviorisms återkomst i Svenskskola [The Return of Behaviorism in the Swedish School]. Pedagogiska Magasinet 2011-05-10 Retrived from http://www. lararnasnyheter.se/pedagogiska-magasinet/2011/05/10/ behaviorismens-aterkomst-svensk-skola.

Fazzio, D. (2014). International interview: With Professor Mickey Keenan, University of Ulster, Northern Ireland. Science in Autism Treatment, 11(2), 11-16.

Fein, D., Barton, M., Eigsti, I. M., Kelley, E., Naigles, L., Schultz, R. T., Stevens, M., Helt, M., Orinstein, A., Rosenthal, M., Troyb, E., \& Tyson, K. (2013). Optimal outcome in individuals with a history of autism. Journal of Child Psychology and Psychiatry, 54, 195-205.

Froján-Parga, M. X. (1998). Consultoría Conductual: Terapia psicológica Breve. [Behavioral consultation: Brief psychological therapy]. Madrid: Pirámide.

Frost, L. \& Bondy, A. (2002). The picture exchange communication system training manual (2nd edition). Pyramid Educational Consultants, Inc.

Gambrill, E. D. (2012). Propaganda in the helping professions. New York: Oxford University Press.

Goupillot, B., \& Keenan, M. (1995). Smacking children. NIBPS Newsletter, 5, 3-6.

Hagopian, L. P. \& Hardesty, S. L. (2014). Applied behavior analysis. Retrieved from the Web 24/11/2014 http://www.kennedykrieger. org/node $/ 13378$.

Hälso och sjukvårdslagen, (1982: 763) [National Health Care Law]. Retrived from http//:riksdagen.se/sv/Dokument-Lagar/Lagar/ Svenskforfattningssamlingar/Halso - och-sjukvårdslag-1982-763.

Health Act (2007) Care And Support of Residents in Designated Centres For Persons (Children And Adults) with Disabilities) Regulations 2013. Statutory Instruments. S.I. No. 367 Of 2013. Dublin: The Stationery Office. Government Publications. Retrieved from the
Web 30/11/2014. http:/hiqa.ie/system/files/Disability-Care-andSupport-Regulations-2013.pdf.

Heward, W. L. (2003). Ten faulty notions about teaching and learning that hinder the effectiveness of special education. Journal of Special Education, 36, 186-205.

Howlin, P. (2013). 70 years of research on autism: how far have we come? Autism Europe Newsletter, Dec. Retrieved from the Web 06/ 07/2014 www.autismeurope.org/files/files/link-autism-60-3.pdf.

Howlin, P., Magiati, I., \& Charman, T. (2009). Systematic review of early intensive behavioral interventions for children with autism. American Journal on Intellectual and Developmental Disabilities, 114(1), 23-41. doi:10.1352/2009.114:23;nd41.

Howlin, P., Savage, S., Moss, P., Tempier, A., \& Rutter, M. (2014). Cognitive and language skills in adults with autism: a 40-year follow-up. Journal of Child Psychology and Psychiatry, 55, 4958. doi:10.1111/jcpp.12115.

Hughes, V. (2011). Researchers track down autism rates across the globe. Retrieved from the Web 05/07/2014 http://sfari.org/news-andopinion/news/2011/researchers-track-down-autism-rates-acrossthe-globe.

Behaviour Analysis in Ireland (2013). Leinster house cross party briefing. Retrieved from the Web 27/04/2014 http:// behaviouranalysisinireland.wordpress.com/2013/06/10/leinsterhouse-cross-party-briefing/comment-page- $1 /$.

Irish Election (2014). Department of education holds 'lingering animosity' to ABA autism education. Retrieved from the Web 24/11/2014 http://www.irishelection.com/2008/02/department-of-educationholds-lingering-animosity-to-aba-autism-education/.

Istituto Superiore di Sanità (ISS) (2011). Linea Guida 21. Retrieved from the Web 29/12/2014 http://www.snlg-iss.it/cms/files/LG_autismo_ def.pdf.

Jacobson, J. W., Foxx, R. M., \& Mulick, J. A. (Eds.). (2005). Controversial therapies in developmental disabilities: fads, fashion, and science in professional practice. Malwah: Erlbaum.

Joint Ministerial Decision Г4/\$.12/oเk.1930/1982 (FEK 724/B'). Approval for implementation of programme of financial aid for severely mentally retarded individuals up to 25 years of age.

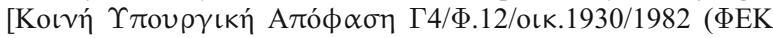

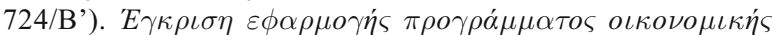
$\varepsilon \nu \iota \sigma \chi \dot{v} \sigma \varepsilon \omega \varsigma \tau \omega \nu \beta \alpha \rho \iota \dot{\alpha} \nu o \eta \tau \iota \kappa \dot{\alpha} \kappa \alpha \theta v \sigma \tau \varepsilon \rho \eta \mu \varepsilon \dot{\nu} \omega \nu \alpha \tau \dot{\mu} \mu \omega \nu$

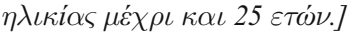

Joint Ministerial Decision $\Pi 3 \alpha / \Phi .18 / Г . П . о เ к .63731 / 2008$ (FEK 931/ B'). Increase in welfare benefits granted to individuals with disabil-

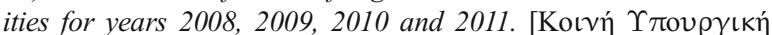
Алó $\phi \alpha \sigma \eta \Pi 3 \alpha / \Phi .18 / \Gamma . \Pi . o เ k .63731 / 2008$ (ФЕК 931/B').

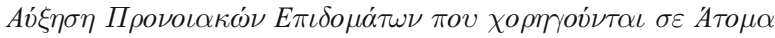

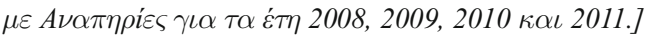

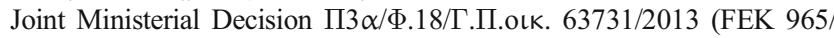
B'). Modification of programme of financial aid of severely mentally

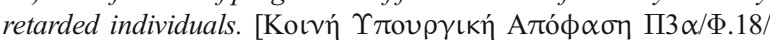

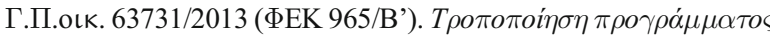

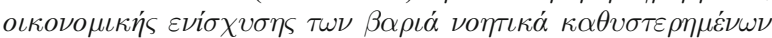
$\alpha \tau o ́ \mu \omega \nu$.]

Jónsdóttir, S.L. \& Eikeseth, S. (2000). Intensive behavioural intervention of children with autism in a pre-school setting in Iceland and Norway. Poster presentation. IX International Congress, AutismEurope, Glasgow 19.-21. May.

Jordan, R. (2001). Parents' education as autism therapists: applied behaviour analysis in context. By M. Keenan, K. Kerr \& K. Dillenburger. Journal of Child Psychology and Psychiatry, 42(3), 421. doi:10.1017/S0021963001216795.

Käck, A., Käck, A., Roll-Pettersson, L. R., Ala i-Rosales, S., Høium, K. Männikkö-Barbutiu, S., \& Fors, U. (2014). Intercultural design considerations; a case study of a blended learning course in autism intervention. European Journal of Online and Distance Education, 17(1), 69-80. 
Kan, C. C., Geurts, H. M., Van den Bosch, K., Forceville, E. J. M., Van Manen, J., Schuurman, C. H., Sizoo, B. B., Stekelenburg, F., Veldboom, E., Verbeeck, W. J. C., Vrijmoed, D., \& Van Duin, D. (2013). Multidisciplinaire richtlijn diagnostiek en behandeling van autismespectrumstoornissen bij volwassenen (Nederlandse Vereniging voor Psychiatrie (NVvP). Nederlands Instituut van Psychologen (NIP)). Utrecht: De Tijdstroom.

Karlsson, P. (2010). Beteende stöd $i$ vardagen: Handbok $i$ tillämpad beteendeanlys. Stockholm: Natur och Kultur.

Kaufman, R. (2013). ABA vs The Son-Rise program. Retrieved from the Web 25/04/2014 www.autismtreatmentcenter.org/contents/other sections/aba-son-rise-program.php.

Keenan, M. (2004). Autism in N. Ireland: the tragedy and the shame. The Psychologist, 17, 72-75.

Keenan, M. (2014). Evidence Based Practice and Autism: A Political Minefield. Retrieved from the Web 27/04/2014, Part 1 https://www. youtube.com/watch?v=LFVykFNOGdw Part $2 \mathrm{https}: / / \mathrm{www}$. youtube.com/watch?v=Y_IXmT57mU8 Part 3 https://www. youtube.com/watch? $\mathrm{v}=\mathrm{BpUU}$ Un $43 \mathrm{zHI}$.

Keenan, M., \& Dillenburger, K. (2011). When all you have is a hammer ...: RCTs and hegemony in science. Research in Autism Spectrum Disorders, 5, 1-13.

Keenan, M. \& Dillenburger, K. (2014). Behaviour analysis: A Primer. iTunes Retrieved from the Web 24/11/2014 https://itunes.apple. com/us/book/behaviour-analysis-a-primer/id564540452?mt=11.

Keenan, M., Dillenburger, K., Röttgers, H.-R., \& Moderato, P. (2010). Science for sale in a free market economy: but at what price? ABA and the treatment of autism in Europe. Behavior and Social Issues, 19, 126-143.

Keenan, M., Martin, N., \& Leslie, J. C. (2013). Leinster House Cross Party Briefing. Retrieved from the Web 27/04/2014 https:// behaviouranalysisinireland.wordpress.com/2013/06/10/leinsterhouse-cross-party-briefing/.

Lambert, C. (2014). Is it right to 'normalise' autism? Retrieved from the Web 27/11/2014 http://www.theguardian.com/education/2013/oct/ 29/specialeducationneeds-autism.

Larsson, E.V. (2013) Is Applied Behavior Analysis (ABA) and Early Intensive Behavioral Intervention (EIBI) an effective treatment for autism? A cumulative review of impartial reports. Retrieved from the Web 25/04/2014 www.abia.net.au/images/Larsson-Is-ABA-andEIBI-an-effective-treatment-for-autism.pdf.

Law 3699/2008 (FEK 199/A'). Special Education and education of people with disability or special educational needs. [Nó $\mu \varsigma$ 3699/

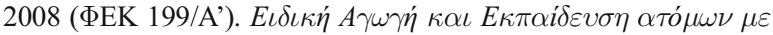

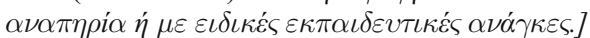

Lovaas, O. I. (1987). Behavioral treatment and normal educational and intellectual functioning in young autistic children. Journal of Clinical and Consulting Psychology, 55(1), 3-9.

Lpöf (1998 revised 2010). Läroplan för förskolan Lpfö 98 [Curriculum for preschool- revised 2010]. Stockholm: Frtiz.

Luciano, M. C. (1996). Manual de psicología clínica: infancia y adolescencia [Clinical psychology handbook: Childhood and adolescence]. Valencia: Promolibro.

Matson, J. L., \& Smith, K. R. M. (2008). Current status of intensive behavioral interventions for young children with autism and PDDNOS. Autism Spectrum Disorder, 2, 60-74.

Maurice, C. (1999). Address to the Cambridge Center for Behavioral Studies (CCBS) Annual Board Meeting, Palm Beach, Florida (Nov. 5). Retrieved from the Web 25/04/2014 www.behavior.org/ resources/266.pdf.

Maurice, C., Green, G., \& Luce, S. C. (Eds.). (1996). Behavioral intervention for young children with autism: a manual for parents and professionals. Austin: PRO-ED.

Maurice, C., Green, G., \& Foxx, R. M. (2001). Making a difference: behavioral intervention for autism. Austin: PRO-ED.
McCormack, P. (2014). Story from the Republic of Ireland. Retrieved from the Web 25/04/2014 www.behavior.org/resources/678.pdf.

Medicare for Autism Now (2014). Families must not fight alone. Retrieved from the Web 27/04/2014 www.medicareforautismnow.org.

Mellon, R. (2005). Behavior Analysis. Athens: Ellinika Grammata.

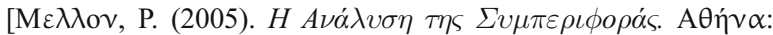

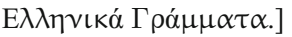

Miltenberger, R. G. (2013). Modificación de conducta ( $5^{\text {th }}$ extended ed.) [Behavior modification]. Madrid: Pirámide.

Milton, D. (2012). The normalisation agenda and the psycho-emotional disablement of autistic people. Autonomy, the Critical Journal of Interdisciplinary Autism Studies, 1, 1-12. Retrieved from the Web 27/11/2014, http://www.larry-arnold.net/Autonomy/index.php/ autonomy/article/view/9.

Ministry of Interior, Public Administration and Decentralization. General Secretariat of Public Administration and Electronic Governance. General Directorate of Administrative Organization and Procedures. (2007). Citizen's with Disability Guide. National

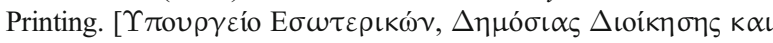

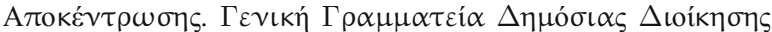

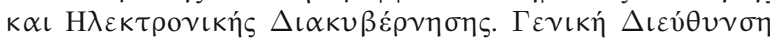

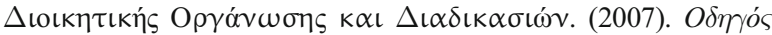

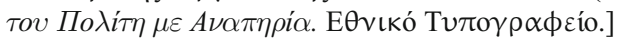

Moderato, P. (2012) Riflessioni sulle linee guida per l'autismo. Psicologia clinica dello sviluppo / XVI, 3, pp 621-624.

Moderato, P. Copelli, C. (2010a). L'Analisi comportamentale applicata (ABA). Autismo e disturbi dello sviluppo, 8-2.

Moderato, P. Copelli, C. (2010b). L'Analisi comportamentale applicata (ABA): teoria, metateoria e fondamenti. Autismo e disturbi dello sviluppo, $8-1$.

Moore, J. (1981). On mentalism, methodological behaviorism, and radical behaviorism. Behaviorism, 9, 55-77.

Moore, J. (1985). Some historical and conceptual relations among logical positivism, operationism, and behaviorism. The Behavior Analyst, 8 , 53-63.

Moore, J. (2001). On distinguishing methodological from radical behaviorism. European Journal of Behavior Analysis, 2, 221-244.

Moore, J. (2008). Conceptual foundations of radical behaviorism. Cornwall-on-Hudson: Sloan.

Mulick, J. A., \& Butter, E. M. (2005). Positive behavior support: A paternalistic utopian delusion. In J. W. Jacobson, R. M. Foxx, \& J. A. Mulick (Eds.), Controversial therapies in developmental disabilities: fads, fashion, and science in professional practice. Malwah: Erlbaum.

Myers, S. M., \& Johnson, C. P. (2007). Management of children with autism spectrum disorders. Pediatrics, 120(5), 1162-1182.

NAS (2014). The National Autistic Society. Position statement: Therapies and interventions. Retrieved from the Web 27/11/2014, http://www. autism.org.uk/news-and-events/media-centre/position-statements/ therapies-and-interventions.aspx.

National Institute for Clinical Excellence (NICE; 2013). Autism in Children and Young People. NICE: Response to Guideline Consultation Comments.

National Institute for Clinical Excellence (NICE, 2014). Management and support in children and young people with autism. Retrieved from the Web 28/11/14 http://pathways.nice.org.uk/pathways/ autism\#path=view $\% 3 \mathrm{~A} /$ pathways/autism/management-andsupport-in-children-and-young-people-with-autism.xml\&content= view-index.

National Research Council, Committee on Educational Interventions for Children with Autism. Lord, C. \& McGee, J. P. (Eds.) (2001). Educating children with autism. Washington, DC: National Academics Press.

Nederlandse Vereniging voor Autisme. (2008). Een plek om te leven. Bilthovden: Nederlandse Vereniging voor Autisme. 
Neidt, E., \& Schenk, J. J. (2012). Behandelprogramma's gebaseerd op de principes van ABA, Een globaal overzicht van toepassingen in Nederland. Wetenschappelijk Tijdschrift Autisme, 2, 47-54.

New York State Department of Health, Early Intervention Program. (1999). Clinical Practice guideline: Report of the recommendations. Autism/pervasive developmental disorders. Assessment and intervention for young children (age 0-3 years). Albany: Author.

Odom, S., Hume, K., Boyd, B., \& Stabel, A. (2012). Moving beyond the intensive behavior treatment versus eclectic dichotomy: evidencebased and individualized programs for learners with ASD. Behavior Modification, 36(3), 270-297.

Orinstein, A. J., Helt, M., Troyb, E., Tyson, K. E., Barton, M. L., Eigsti, I.-M., Naigles, L., \& Fein, D. A. (2014). Intervention for optimal outcome in children and adolescents with a history of autism. Journal of Developmental and Behavioral Pediatrics, 0, 1-10.

Parsons, S., Charman, T., Faulkner, R., Ragan, J., Wallace, S., \& Wittemeyer, K. (2013). Commentary-bridging the research and practice gap in autism: the importance of creating research partnerships with schools. Autism, 7(3), 268-280.

Pellon, R., \& Blackman, D. E. (1987). Punishment of schedule-induced drinking in rats by signaled and unsignaled delays in food presentation. Journal of the Experimental Analysis of Behavior, 48, 417434. doi:10.1901/jeab. 1987.48-417.

Peters-Scheffer, N. C. (2013). Fostering development in young children with autism spectrum disorder and intellectual disability: a centerbased discrete trial approach. Dissertation: Radboud University Nijmegen.

Peters-Scheffer, N. C., Didden, R., Korzilius, H., \& Sturmey, P. (2011). A meta-analytic study on the effectiveness of comprehensive ABAbased early intervention programs for children with autism spectrum disorders. Research in Autism Spectrum Disorders, 5, 60-69.

Peters-Scheffer, N. C., Verschuur, R., Huskens, B. E. F. M., \& Didden, R. (2014). Applied Behavior Analysis bij kinderen met autism spectrum stoornissen en/of verstandelijke beperking. In P. Goudena, R. De Groot, \& J. Janssens (Eds.), Orthopedagogiek: stage of the art (9th ed.). Apeldoorn-Antwerpen: Garant.

Ramnerö, J., \& Törneke, N. (2013). Beteendets ABC: en introduktion till behavioristisk psykoterapi. Stockholm: Studentlitteratur.

Reese, E. P., Howard, J., \& Reese, T. W. (1979). Human operant behavior. Analysis and application. Dubuque: Brown.

Reichow, B., \& Wolery, M. (2009). Comprehensive synthesis of early intensive behavioral interventions for young children with autism based on the UCLA Young Autism Project model. Journal of Autism and Developmental Disorders, 39, 23-41.

Research Autism (2014). Applied behaviour analysis and autism. Retrieved from the Web 25/11/2014 http://researchautism.net/ autism-interventions/our-evaluations-interventions/120/appliedbehaviour-analysis-and-autism.

Rijksoverheid Nederland. (2013). Speciaal onderwijs. Retrieved from the Web 01/11/2014 http://www.rijksoverheid.nl/onderwerpen/passendonderwijs/speciaal-onderwijs.

Roll-Pettersson, L., \& Ala i'-Rosales, S. (2009). Using blended and guided technologies in a university course for scientist-practitioners: teaching Applied Behavior Analysis to autism professionals. Journal of Intellectual Disabilities, 13(2), 113-142.

Roll-Pettersson, L. \& Olsson, I. (2015). Putting pieces together; Implementation of IBI in Swedish preschools exemplified through a case-study approach. In preparation

Roll-Pettersson, L., Ek, U. \& Ramnerö, J. (2010). Benefits of BACB Certification for Universities in Europe: A Case Study from Sweden. Association of Professional Behavior Analysts, issue 17.

Ruane, C. (2009). Answer to Ministerial Question from George Robinson. Department of Education (letter dated June, 17).

Ruiz, M. R. (1995). B. F. Skinner's radical behaviorism: historical misconstructions and grounds for feminist reconstructions. Behavior and Social Issues, 5, 29-44. http://journals.uic.edu/ojs/index.php/ bsi/article/viewfile/224/2150.

Salomone, E., Beranová, S., Bonnet-Brilhault, F., Lauritsen, M. B., Budisteanu, M., Buitelaar, J. et al., (2014). Use of early intervention for young children with autism spectrum disorder across Europe. (under review)

Schopler, E., Reichler, R. J., \& Lansing, M. (1980). Individualized assessment and treatment for autistic and developmentally disabled children. Vol. 2: Teaching strategies for parents and professionals. Austin: Pro-Ed.

Schothorst, P. F., Van Engeland, H., van der Gaag, R. J., Minderaa, R. B., Stockmann, A. P. A. M., Westermann, G. M. A., \& Floor-Siebelink, H. A. (2009). Richtlijn diagnostiek enbehandeling autismespectrumstoornissen bij kinderen en jeugdigen. Nederlandse Vereniging voor Psychiatrie. Utrecht: De Tijdstroom.

Scott, C. (2014). Tough love. Sunday Times Magazine (April, 13), 41-45.

Sidman, M. (2000). Coercion and Its Fallout Boston: Authors Cooperative Inc. Publishers.

Sigurdardóttir, Z. G., Pétursdóttir, A.-L., Jónsdóttir, S. L., \& Magnússon, A. F. (2013). Report on the need for a new program in applied behavior analysis at the University of Iceland [Um pörf á nýrri námsleið $i$ hagnýtri atferlisgreiningu við Háskóla Íslands]. Reykjavík: The University of Iceland and the State Diagnostic and Counselling Centre.

Skinner, B. F. (1952/1977). Ciencia y conducta humana [Science and human behavior]. Barcelona: Fontanella. Original document published 1953.

Skinner, B. F. (1974/1977). Sobre el conductismo [About behaviorism]. Barcelona: Fontanella. Original docuement published 1974.

Skollagen (2010:800) [Swedish Education Act]. Stockholm; Nordstedts Juridik AB.

Smith, T. (2013). What is evidence-based behavior analysis? The Behavior Analyst, 36, 7-33.

Smith, T., Groen, A. D., \& Wynn, J. W. (2000). Randomized trial of intensive early intervention for children with pervasive developmental disorder. American Journal on Mental Retardation, 105, 269-285.

STAMPPP (2014). Science and the treatment of autism. Retrieved from the Web 06/07/2014 www.stamppp.com.

Surgeon General. (1999). Mental health: A report of the Surgeon General. Bethesda, MD: U.S. Public Health Service. Retrieved from the Web 06/01/2014 http://profiles.nlm.nih.gov/ps/retrieve/ ResourceMetadata/NNBBHS.

The Pre-School Act [Lög um leikskóla], no. 90/2008. Retrieved from the Web 21/10/2014 http://planipolis.iiep.unesco.org/upload/Iceland/ Iceland_Preschool_Act_2008.pdf.

The Skeptical Advisor (2014). Simon Baron-Cohen's fantastically false article on Radical Behavior: An example of valid, but false premises (see all comments) Retrieved from the Web 06/01/2014 http:// theskepticaladvisor.wordpress.com/2014/01/21/simon-baroncohens-fantastically-false-article-on-radical-behavior-an-exampleof-valid-but-false-premises/.

Todd, J. T., \& Morris, E. K. (1983). Misconception and miseducation: presentations of radical behaviorism in psychology textbooks. The Behavior Analyst, 6, 153-160.

Unumb, L. (2013). Let me hear YOUR voice. Autism and politics. Retrieved from the Web 06/01/2014 www.mediator.qub.ac.uk/ms/ Quart/DrLorriUnumb.m4v.

Virues-Ortega, J., Shook, G. L., Arntzen, E., Martin, N., Rodríguez García, V., \& Rebollar Bernardo, M. (2009). Professional field and certification in applied behavior analysis: Spain and Europe. Papeles del Psicólogo, 30, 155-163. Retrieved from the Web 24/11/2014 http://www.papelesdelpsicologo.es/english/1704.pdf

Walsh, P. (1997). Bye-bye behaviour modification. In K. Dillenburger, M. F. O'Reilly, \& M. Keenan (Eds.), Advances in behaviour analysis. Dublin: University College Dublin Press. 
Warren, Z., McPheeters, M. L., Sathe, N., Foss-Feig, J. H., Glasser, A., \& Veenstra-Vanderweele, J. (2011). A systematic review of early intensive intervention for autism spectrum disorders. Pediatrics, 127(5), 1303-1311.

Webster, J. (2011). Thank you, Dr. Lovaas. Retrieved from the Web 06/ 07/2014 http://specialed.about.com/b/2011/02/10/thankyou-drlovaas.htm.

Landschaftsverband Rheinland und Westfalen-Lippe (2014). Federation of city councils in the state of Northrhine-Westphalia:
Recommendations for interventions for children and adolescents paid for by the local social care authorities.

Wing, L. (1966). Early childhood autism, clinical, educational and social aspects. Oxford: Pergamon.

Zakirova Engstrand, R., \& Roll-Pettersson, L. (2012). A Swedish Context; Preschool teacher efficacy and attitudes toward inclusion of children with autism. Journal of Research in Special Educational Needs. doi:10.1111/j.1471-3802.2012. 01252.x. 